\title{
Realismo e (des)subjetivação: as várias faces da fome em três momentos da Literatura Brasileira
}

\author{
Valéria Aparecida de Souza Machado*
}

\begin{abstract}
Resumo
Este texto discute como e por quais vias se processa a construção subjetiva em três romances da literatura brasileira: A fome, de Rodolfo Teófilo; Vidas secas, de Graciliano Ramos e Homens e caranguejos, de Josué de Castro. Usualmente classificados de realistas, os romances, produzidos em épocas e contextos distintos, têm em comum o tratamento da temática da fome. Considerando-se os textos analisados como construções em que os conceitos de real e realidade são entendidos diferentemente, optou-se por aproximar o conceito de realismo ao de formação discursiva (Foucault, 1995), esta compreendida como um saber constituído de discursos sobre algo, envolvendo sujeitos que ocupam posições diferentes de acordo com o tempo e o espaço de onde enunciam. O conceito de formação discursiva também se alinha ao de subjetivação na medida em que, como seres de linguagem, os sujeitos constituem a si e as coisas no momento em que falam, construindo sentidos nas e pelas relações que os envolve. Nessa perspectiva, propõe-se entender a realidade e o próprio realismo em suas fronteiras móveis, já que aí estão em jogo discursos, sujeitos, tempos e espaços.
\end{abstract}

Palavras-chave: Realismo. Romance. Formações discursivas. Fome. Subjetivação.

Uma questão que motivou a escolha do objeto que aqui se discute - o realismo em três fases da história da literatura brasileira ${ }^{1}$ - relaciona-se à polêmica que vem envolvendo as produções culturais, especialmente a literatura, ligadas àquilo que se denomina a estética realista em sua relação com a representação da realidade. Pela amplitude do objeto foi necessário delimitar o tema, motivo pelo qual se elegeram romances que tratam a questão da fome. São produções situadas em

* Pontifícia Universidade Católica de Minas Gerais - (PUC Minas). Doutora em Literaturas de Língua Portuguesa. Bolsista CAPES.

$1 \mathrm{O}$ presente artigo foi elaborado a partir da tese de doutorado da autora, intitulada "Fome e corpo; seca e lama: realismo e (des)subjetivação em três momentos da literatura brasileira", defendida em setembro/2016 pelo Programa de Pós-graduação em Letras da PUC Minas, área de concentração Literaturas de Língua Portuguesa. 
momentos históricos distintos e, por isso mesmo, com tratamento diferenciado da temática que lhes é comum, mas não sem guardarem semelhanças: A fome, de Rodolfo Teófilo; Vidas secas, de Graciliano Ramos e Homens e caranguejos, de Josué de Castro. O que importa analisar, mais do que o contexto histórico dos romances ou os aspectos sociais envolvidos em sua temática, é o modo como esses discursos confrontaram a questão da fome, aliada, sobretudo, à condição subjetiva do indivíduo que a experimenta nas situações encenadas pelos romances.

Já de início, dois elementos são encarados na condução da investigação: o gênero romanesco e o estilo realista, o que convida a pensar na relação entre literatura e realidade; entre realismo e romance. Considerando-se o romance como um gênero em que se manifesta a condição histórico-social do homem, do homem que fala (BAKHTIN, 2010), um outro elemento é introduzido na discussão: a questão da subjetivação, sempre levando em conta que, como seres de linguagem, os sujeitos se constituem no momento em que falam, por meio dos discursos que proferem.

Num primeiro momento, pode parecer contraditório aproximar realismo e subjetivação, sobretudo se se pensa o realismo por uma perspectiva tradicional, aquela que o toma apenas como um modo pretensamente objetivo de representação do mundo empírico. Diferentemente, o que se propõe aqui é compreender o realismo como um dentre os tantos modos de se pensar esteticamente a relação do homem com o mundo. Por isso mesmo, importa considerar as modificações que o conceito sofreu ao longo do tempo, relativamente aos três momentos considerados, na medida em que o próprio conceito de realidade foi encarado de maneiras diferentes, como resultado dos lugares de enunciação distintos ocupados pelos escritores. Acrescente-se que a concepção de romance aqui considerada é a que o vê como um gênero assimétrico, inacabado (Bakhtin, 2010), que admite a diversidade de pontos de vista, a singularidade dos variados lugares de enunciação implicando, inclusive, diferentes leituras.

Nessa perspectiva, de modo a melhor distinguir os diversos momentos do que é chamado de realismo e sem perder de vista o trabalho com as cenas enunciativas, optou-se por alinhar o conceito de realismo ao de formação discursiva, compreendida por Michel Foucault (1995) como um saber constituído pela prática de discursos sobre algo, em um tempo e lugar. Não se trata de um saber preestabelecido, mas que muda de acordo com os discursos que o atravessam e as posições que os sujeitos ocupam. A formação discursiva, segundo o autor, não estaria na ordem 
do fixo, da unidade, mas do heterogêneo, daquilo que possui fronteiras móveis. Assim, deixa-se de ver a formação discursiva pela perspectiva da unidade e da continuidade, para considerá-la como algo constituído de temporalidades (e espacialidades) múltiplas, na perspectiva sustentada por Foucault:

[...] uma formação discursiva não desempenha, pois, o papel de uma figura que para no tempo e o congela por décadas ou séculos: ela determina uma regularidade própria de processos temporais; coloca o princípio de articulação entre uma série de acontecimentos discursivos e outras séries de acontecimentos, transformações, mutações e processos. Não se trata de uma forma intemporal, mas de um esquema de correspondência entre diversas séries temporais. (FOUCAULT, 1995, p. 82).

Isso não significa que as formas de continuidade discursiva sejam desprezadas, mas considera-se que elas podem ser postas em causa por discursos que recortam, questionam, transformam o objeto sobre o qual se fala e, por isso mesmo, vão se marcar como modos de descontinuidade e de ruptura (FOUCAULT, 1995).

$\mathrm{O}$ conceito de formação discursiva pode ser pensado, ainda, no campo da constituição subjetiva, quando se considera a questão da enunciação, quer dizer, os sujeitos constituem a si e as coisas no momento em que falam, o que significa que não há sentido prévio, mas construído nas relações que envolvem as práticas discursivas em determinado tempo e lugar; nas enunciações de sujeitos historicamente localizados. Tal perspectiva aponta para o desmanche da ideia de realidade como algo já dado, sugerindo a mobilidade que envolve o conceito, sobretudo quando se considera que os sujeitos mudam de lugar e desempenham papéis diferentes, o que os leva, assim como a realidade e o próprio conceito de realismo, a serem compreendidos em suas fronteiras móveis. Por isso mesmo, a posição de Foucault (1995) se alinha à de Bakhtin (2010) e Benveniste (1989a; 1989b; 2005), se se pensa que no bojo das formações discursivas estão articuladas as relações entre linguagem, sujeito, tempo e espaço, elementos que sustentam a constituição subjetiva.

É nessa perspectiva da formação discursiva que o realismo está sendo tratado, justamente para se perceber o que abriga esse rótulo nos três momentos da história da literatura brasileira considerados. Assim, toma-se o realismo como uma grande cena enunciativa que se divide em três quadros enunciativos, cada um correspondendo aos momentos de produção dos romances selecionados. Os 
romances são analisados sempre em seu momento de enunciação, buscando-se perceber qual a concepção de realidade que aí circula, de que modo cada um se organizou textualmente deixando ver, no tratamento da fome, que base comum do realismo se repete e que diferenças são instauradas, levando a rupturas.

Interessa considerar três momentos na história do realismo no Brasil. Primeiramente, o naturalismo do século XIX, de índole determinista voltada para a relação do homem com o ambiente, em que o culto do factual e do documental parecia estar relacionado com o processo de construção da identidade nacional de um país que precisava afirmar-se diante de sua recente independência. É nesse momento que se enquadra o romance A fome, de Rodolfo Teófilo (2011). Outro momento, já no século XX, está ligado ao realismo da década de 1930, mais voltado para o tratamento de questões locais e regionais, cuja feição realista, também chamada de neorrealista, foi fortemente marcada pela crítica das relações socioeconômicas. Enquadra-se, aí, o romance de Graciliano Ramos, Vidas secas (1998). Finalmente, o momento que compreende o realismo da década de 1960/1970, de viés mais político e também crítico, que se volta para a problematização da vida nas grandes cidades e busca uma nova linguagem capaz de dar conta da realidade social urbana. Aí faz-se o enquadramento do livro de Josué de Castro (2010), Homens e caranguejos. É preciso ter em conta, no entanto, que, mesmo dentro desse enquadramento histórico-temporal, os romances apresentam elementos que destoam das propostas estético-literárias comuns a outras produções do mesmo período, o que os coloca no campo da diferença e da descontinuidade.

O romance de Rodolfo Teófilo, A fome, publicado em 1890, narra a saga de uma família que deixa o sertão, fugindo da seca, rumo à capital cearense. É o primeiro romance brasileiro a tratar o tema da fome. $\mathrm{Na}$ época, o Brasil, apesar de pouco desenvolvido, entrava em sua fase urbano-industrial exigindo reformas na sociedade, de modo a alinhar o país ao modelo desenvolvimentista que dominava o século XIX. Invitável, nesse processo, o choque de posturas, levando a um movimento de renovação também da cultura nacional, em que se percebe a incorporação, pelo pensamento intelectual brasileiro, das ideias cientificistas e positivistas vigentes na época. Isso teve reflexos profundos na produção literária brasileira que também passa de uma fase a outra. $O$ realismo e também o naturalismo impõem-se como reação ao romantismo, intensificando a busca pelo factual, pelo empiracamente observável como tentativa de se acercar da vida e dos problemas cotidianos de modo pretensamente objetivo. A preocupação com a 
inferência, com o rigor da objetividade narrativa, com a análise das personagens e suas ações pelo viés da ciência fez com que o naturalismo se constituísse a base a partir da qual os problemas da sociedade poderiam ser pensados pela via da literatura.

A formação de Rodolfo Teófilo esteve totalmente voltada para a área da ciência: era farmacêutico, cientista experimentador, sanitarista. Apesar de ter tratado de um tema incômodo para a época, é preciso notar a ambiguidade que ronda a construção do livro quando se considera que, no âmbito da literatura naturalista, insere-se um projeto de higienização da sociedade - e do qual Rodolfo Teófilo participa - em que era preciso apontar aqueles aspectos da realidade social que precisavam ser corrigidos. Tal lugar de enunciação ocupado pelo autor explica as escolhas privilegiadas na organização do romance.

Em A fome o corpo ocupa todo o espaço textual para ser mostrado em seu estado de depauperação e corrosão, abatido pela fome. Tal ideia é estendida ao ambiente e ao corpo social com suas instituições. À fome propriamente dita associam-se, pois, outras fomes: a fome de poder, a fome de justiça, o apetite sexual. Em sua estrutura linear, a narrativa é marcada, do início ao fim, pela experiência que envolve corpos e ambientes degradados pela seca, pela fome e pela morte. As cenas, muitas vezes beirando o nível do absurdo ou da abjeção, são narradas por um narrador oniscente, de $3^{\text {a }}$ pessoa, que ocupa o lugar de alguém portador de vários saberes, principalmente o médico-científico. Tal estratégia conferiria um tom de autoridade e credibilidade ao narrado, além de marcar a escrita em sua relação com o próprio autor.

A fome é metonímia síntese das penúrias da seca em que o corpo aparece hipertrofiado, configurado em sua relação com a morte, além de associado ao animal, ao lixo, ao impuro; reificado pelo excesso naturalista marcado na escrita. A dimensão fisiológica do corpo o coloca como um objeto a ser mapeado, inventariado, como na cena em que os escravos são submetidos a exames médicos minuciosos, legitimando o discurso médico incorporado na voz do narrador. Ora o homem é animalizado, comparado ao animal pela própria posição de corpos que se põem "de gatinhas ou de rastos, como répteis" (TEÓFILO, 2011, p. 77), ora objetivado, como no caso dos escravos, considerados "peças" a serem vendidas. Em casos extremos, o homem aparece devorado pelo animal, como nas cenas que mostram urubus que comem as vísceras de uma mulher ainda viva, morcegos que sugam o sangue de uma criança semimorta ou o cão que se banqueteia do corpo 
do dono morto. O corpo configura-se como um objeto sobre o qual se fala, o que aponta para a impossibilidade de diálogo diante do homem coisificado. O processo de dessubjetivação se dá, além do movimento de animalização e objetivação, na subjugação e no aviltamento do corpo ou no silenciamento da voz pelos que detêm o poder, tal como ocorre com a violação de escravas virgens pelo traficante de escravos ou as surras sem motivo dadas nos escravos, pelo simples prazer de ver seus corpos açoitados.

Assim como a ideia de morte percorre os vários espaços da narrativa, a ideia de apodrecimento também é configurada em suas diversas dimensões. Em cenas degradantes que mostram retirantes assaltando comboios de víveres, homens lutando pela disputa agressiva do alimento, corpos doentes que agonizam nos lazaretos ou mortos enterrados em valas comuns, surge um cenário de desagregação da própria organização social. O comportamento das personagens explica-se pelos diversos determinismos, bem ao gosto naturalista: a influência do meio, como a promiscuidade que envolve cenas de orgia; da raça, a justificar a indolência dos escravos; da hereditariedade, entrevista nas doenças herdadas de gerações passadas.

Ao mesmo tempo em que mostra a deterioração dos corpos, espaços e instituições, o romance apresenta modelos, deixando ver sua filiação a um projeto de construção de uma identidade nacional. Em contraposição ao homem animalizado, objetivado e emudecido pela fome e pela degradação física e moral, está o homem branco, letrado, racional, que pensa e fala, saudável física e moralmente, modelo incorporado, por exemplo, na figura do protagonista Manuel de Freitas e do narrador. $\mathrm{O}$ mesmo se dá em relação aos espaços: em contraste com aqueles contaminados e degradados - os lazarentos, os prostíbulos, a senzala - estão os ambientes limpos e higienizados das casas burguesas, de amplas janelas e paredes claras, que compõem a área central da cidade. O processo de construção da nacionalidade que vai embutido na construção do romance esbarra, assim, nos procedimentos de ordenamento e limpeza que querem moldar o corpo do cidadão e as instituições sociais. A esse processo corresponde, em contrapartida, o de segregação e exclusão daqueles que não se enquadram no modelo de "corpo saudável/são" a que corresponderia a ideia de formação moral do indivíduo. Ressalta-se, com isso, o aspecto moralizador e pedagógico do livro que mostra o errado, o degradante, o apodrecido como casos que precisam de reforma e tratamento. Daí, também, sobressai a ênfase dada à função que a literatura teria, 
na construção do romance, de educar e civilizar, incorporando o cientificismo e a concepção de progresso ao projeto de construção da identidade nacional.

Vidas secas foi publicado em 1938, um ano após Graciliano Ramos ser libertado da prisão e em um momento de consolidação do Estado Novo e do governo ditatorial de Getúlio Vargas. Foi uma época de instabilidade política e econômica em razão dos problemas gerados no período pós-revolução de 1930, em que o país tentava consolidar sua economia de base industrial capitalista. No acirramento de forças políticas pela disputa de poder prevaleceu o projeto autoritário do Estado Novo, cujo fechamento político, decorrente do regime ditatorial, abalou a crença no processo de modernização como via possível para minimizar a abismo econômico e as desigualdades sociais. Simultaneamente a essas questões, ganham força movimentos empenhados em promover mudanças, movidos pela vontade de redefinir a vida e a cultura nacionais. A intelectualidade brasileira, apesar de polarizada, marca-se por sua maior participação na vida pública do país e pelas posturas mais críticas em relação aos problemas da sociedade, sobretudo vista em suas contradições. Nesse período há uma mudança no conceito de intelectual e de seu papel de atuação na vida pública (CANDIDO, 1984), repercutindo no aumento da produção de ensaios e romances que deixam ver a vontade de analisar criticamente a realidade do país. Esses lugares de fala marcam, portanto, um tipo de formação discursiva denominada "romance de 30 ", enquadrado na perspectiva do neorrealismo, de viés crítico e marxista, que vê os problemas e desigualdades da realidade social como fruto das relações socioeconômicas.

É preciso considerar, no entanto, que mesmo aquele intelectual de postura esquerdista ocupou lugar ambíguo nesse cenário, já que sua participação na vida política do país também esteve ligada a todo um aparato cultural voltado a produzir e sustentar a ideologia do Estado, principalmente na difusão de uma consciência de nação. Nesse panorama é que se insere Vidas secas, sendo válido ressaltar que a participação de Graciliano Ramos aí não se deu pela via do endosso ao projeto de nação encabeçado pelo governo de Getúlio Vargas, o que não significa ausência de expectativa em relação a um projeto de nacionalidade. Na verdade, sua atuação marca-se pelo desmanche de um projeto de nação tal como queria a história oficial. Daí o empenho em mostrar as mazelas do país, seu povo acossado e oprimido, tudo que por ser diferente e destoante era escamoteado pela história oficial em sua proposta de uma identidade unificada. 
Vidas secas também encena a fome, a escassez, a vida miserável de uma família de retirantes que foge da seca em busca de dias menos difíceis, o que aponta para a tensão entre esse homem acossado e a sociedade que o oprime. Aí o conceito de realidade não se pauta na força de determinismos, mas nos jogos de poder que envolvem as relações socioeconômicas. Há, no romance de Graciliano Ramos, a intenção social que aponta a opressão, a exploração, as relações de poder, mas ela não aparece como denúncia direta. A "matéria" conjuga-se com a "fatura do texto", nos termos de Antonio Candido (1984), o que significa dizer que é no plano da escrita, da organização textual que está a condição para a compreensão da intenção social entrevista no livro. No entanto, mais do que a intenção social, Graciliano Ramos preocupa-se em perscrutar a condição humana, em mostrar o sertanejo em sua relação com outros sujeitos e espaços por onde transita.

A estrutura fragmentária do romance, cujos capítulos podem ser lidos como contos, aponta para uma estratégia que encena a falta de um senso de ordenação das personagens em relação aos valores que regem a ordem social estabelecida da qual estariam fora. No entanto, o que aparenta independência e autonomia vai, aos poucos, sendo entrelaçado numa teia que indicia sentidos; a estrutura fragmentária se organiza, coincidindo com a organização do caos que, a princípio, rege a vida das personagens, o que se dá a partir do momento em que tomam consciência de sua condição humana e histórica.

Assim como A fome, o romance de Graciliano também joga com a ideia de vida e morte e, ainda, com a condição de sujeito e objeto, homem e bicho. São, no entanto, relações oscilantes e não dicotômicas, já que tais condições coexistem e interagem na construção do texto e das personagens. Paisagem e personagens parecem, num primeiro momento, não se distinguirem; são construídas de forma imbricada. A tortura da paisagem coincide com a dor e o sofrimento das personagens. A escrita, com seu estilo de frases curtas e texto enxuto, também mantém correspondência com a secura e a escassez que marcam paisagem e personagens. Na construção do processo enunciativo, destaquem-se o modo como o narrador é construído e o jogo de aproximação e distanciamento no interior das cenas. $\mathrm{O}$ narrador não fala no lugar das personagens, nem fala por elas, mas endossa o que falariam como se marcasse seu lugar de enunciação. Aí se entrevê o intelectual em sua tensa relação com a palavra, na medida em que põe em causa sua própria capacidade de representar o outro, mesmo sabendo que é pela palavra que a natureza humana pode ser compreendida. 
O romance dá dimensão ao corpo, mas sempre o relaciona ao gesto, ao olhar, ao balbucio, ao sensorial, a outros índices que o narrador traduz como um movimento de se colocar diante do outro, mesmo pelo que não é dito. Há um gesto do próprio autor em sua escrita a indicar que suas personagens, mesmo iletradas, de pouca fala, de pouca valia na estrutura social, são também sujeitos que dizem, a seu modo, sua singular maneira de estar no mundo. Interessa, por isso mesmo, o modo como as personagens são construídas pelo romance, como ocorre, por exemplo, com Fabiano. Aparentemente constituído como um tipo - o sertanejo retirante explorado, tornado bruto pela situação de privação e fome - o autor dá a conhecer a natureza desse sujeito tentando enxergá-lo no jogo das relações sociais. No movimento que envolve a aproximação e o distanciamento do narrador, despemse as máscaras impostas a Fabiano (de bruto, animal, objeto) e a narrativa o mostra como um indivíduo fragmentado que busca a compreensão de si e de suas próprias contradições. Não é por acaso que o questionamento que ele se faz o tempo todo é o meio pelo qual a narrativa será conduzida: ser bicho ou ser homem; ser sujeito ou objeto. Fabiano é construído aos poucos, dividindo tal tarefa com o narrador que também ocupa o papel de interlocutor. O próprio narrador sofre deslocamentos e, ao se distanciar, marca seu lugar de saber, erudito, letrado, sem negar o lugar de saber do sertanejo. Em outros momentos, a aproximação faz parecer que ele adota o ponto de vista das personagens. A escrita de Vidas secas é, assim, marcada como um espaço comum (RANCIÈRE, 2009) que acolhe o heterogêneo, o diferente; como um espaço de encontro de percepções individuais discordantes que são postas em diálogo.

Simultaneamente à construção das cenas, a subjetividade das personagens também se constrói. Um exemplo é a cena em que Fabiano se acha mudado pela falta de coragem de se vingar do soldado amarelo. Aí se estabelece a tensão entre o primitivo e a cultura, a transformação de bruto em humano. Note-se que é conforme os lugares de enunciação que ocupam e das relações que estabelecem que as personagens vão se construindo, o que aponta para uma construção intersubjetiva. Fora do espaço da cidade e da cadeia, onde exerce seu poder sobre o outro, o soldado amarelo é visto por Fabiano em sua fragilidade. O mesmo acontece com Fabiano, sinhá Vitória e os meninos quando entram no espaço da cidade e se sentem cada vez mais fora dela ao tentarem, inutilmente, adaptarem-se a suas leis e regras. 
Ao colocar espaços e tempos em diálogo, a escrita de Vidas secas também coloca forças em tensão: de um lado o homem desventurado e oprimido, mas que pensa, sonha, deseja e, de outro, a sociedade que o marginaliza e exclui. A oscilação entre ser homem e ser bicho/objeto é encenada nas diversas situações vividas pelas personagens em que sobressai sua construção social como seres brutos, animalizados, reificados. A proximidade com o mundo animalizado está para além do corpo biológico; alcança o comportamento, as atitudes, a linguagem. Tal condição é reforçada quando se pensa no movimento de humanização da cachorra Baleia que é, de fato, quase humana. É, pois, por um processo inverso que a narrativa mostra a humanização das personagens; pela via do animal realça-se o humano. Mas, no jogo ambíguo, o animal, humanizado, morre e as personagens se mantêm vivas porque movidas pelo sonho e pelo desejo; pela capacidade de rememorar e temporalizar.

Num movimento que desconstrói o que a sociedade impõe às personagens, a narrativa, na ambiguidade que envolve o jogo entre brutalidade e humanidade, concede espaço para que elas se construam subjetivamente através dos sonhos e desejos. Na sutileza do texto isso aparece, por exemplo, na imagem da cama desejada por Vitória que representaria o objeto inatingível que a move em seu sonho; ou, ainda, no uso do futuro do pretérito a indicar possibilidade, hipótese e, logo, sonho. Ligada ao sonho e ao desejo está a linguagem que, durante toda a narrativa, é o motivo de perturbação e júbilo das personagens. Nesse jogo, o texto de Graciliano constrói um movimento ascendente de humanização das personagens que não se desvincula do movimento que leva à consciência da linguagem ou, mais que isso, da construção de sentidos pela linguagem. No último capítulo isso fica bastante claro, quando a linguagem ocupa o lugar do desamparo, do real que não pode ser dito (a seca, a fome, a morte), levando sinha Vitória à necessidade de falar. Digno de nota é o modo como é tecida a construção de sentidos em relação a Fabiano: de mero repetidor da palavra alheia ele é deslocado e posto diante da (im)possibilidade de lidar com a linguagem na pergunta do filho e na frase, a princípio "sem sentido" de sinhá Vitória sobre as aves de arribação. O que o perturba é justamente aquilo que lhe falta, mas que ele deseja significar, simbolizar. É, pois, na relação com o outro, tendo a linguagem como ponte, como elemento mediador ligando interlocutores, que as personagens de Vidas secas se constroem subjetivamente. 
Homens e caranguejos, publicado em 1967, narra a história de um menino que foge da seca com a família para viver nos mangues do Recife, onde divide, com os caranguejos, um espaço de miséria e fome. É o único romance do médico e cientista político Josué de Castro, conhecido por sua significativa produção de estudos e ensaios científicos, de análise sociológica do fenômeno da fome. Josué de Castro escreve o livro no período em que se encontra exilado na França em razão de seus direitos políticos cassados pela ditadura militar. Ainda que nessa época a censura concedesse certa liberdade para a produção de obras de cunho contestatório, alguns temas, principalmente aqueles que expunham os problemas da sociedade brasileira, eram tidos como 'proibidos', entre eles, a fome. Pela impossibilidade de atuar politicamente no combate a essa questão pela via do documental e do científico, como usualmente fazia, o autor parece valer-se da literatura para tornar visível o problema da fome que, segundo ele, estava excluído dos debates. Assim, percebe-se, no romance, o esboço de um movimento que busca transformar a fome em uma espécie de força que pudesse abalar os centros de poder, já que vista como uma vergonha nacional.

A escrita do livro é marcada pela ideia de hibridez não só em relação à forma, já que mistura romance, memórias, autobiografia, mas dos corpos marcados pela fome, os homens-caranguejo, sem contar o próprio espaço do mangue, formado pela mistura de água e terra. A mistura de elementos, de fatos, de histórias, inclusive a do próprio autor, aponta para a construção de subjetividades no espaço do texto, a do narrador e as personagens em jogo com a do próprio autor. Tempos e espaços também se embaralham, privilegiando-se o sensorial, a experiência, o que mostra a divergência entre as formações discursivas dadas como realistas, porque mesmo preocupadas com o referente, estão ligadas ao sujeito autor e suas vivências. E é considerando o lugar de enunciação do autor que se nota certo tom pedagógico, a despeito do caráter revolucionário que perpassa a escrita do livro, ao tratar o tema da fome, além de sua dicção social que aponta para as relações socioeconômicas em sua relação com o fenômeno da fome.

Em sua intenção social, o romance mostra, na construção dos espaços, o abismo que separa os habitantes do mangue e os da cidade; ambientes de fartura e miséria (apesar de isso se dar de modo mais dicotômico do que em diálogo) a exibir a atitude aplainadora que exclui aqueles segmentos sociais em dissonância com a ordem estabelecida. Além disso, há menção à exploração que envolve o ciclo do capital, as relações desiguais entre patrões e empregados, usineiros e 
camponeses, pondo à mostra o privilégio dos detentores dos meios de produção. Nessas relações, o romance deixa ver o silenciamento de vozes e a pouca valia dos menos favorecidos na engrenagem que mantém o sistema, aí envolvido o corpo social com suas instituições, essas representadas nas figuras de políticos, donos de indústrias e proprietários de terra que, de alguma forma, mantêm o ciclo da miséria e da fome.

O mangue aparece constituído biologicamente de restos e rejeitos, de matériaprima em decomposição, mas rico em biodiversidade. Do mesmo modo, os que habitam esse espaço são os indivíduos que a sociedade organizada rejeita; histórias várias que vão compor a história do mangue. Por isso mesmo ele é desenhado como espaço de refugo, exclusão; de pobreza e fome, mas também de diversidade (biológica e social) e de resistência. Não por acaso o nome de "Aldeia Teimosa" que pode referir-se tanto às raízes fixas na terra lodosa, quanto aos mocambos reconstruídos no mesmo lugar depois das cheias, teimando em resistir aos projetos higienizantes da cidade ordenada.

A relação imbricada entre mangue, homem e caranguejo remete ao ser híbrido criado a partir da metáfora homem-caranguejo, indicando a interdependência ligando natureza, homem e animal. No processo de transformação do homem em caranguejo, exibe-se o movimento de dessubjetivação do primeiro que, rejeitado e excluído socialmente, é empurrado para o mangue onde passa a fazer parte da "lama social" que sustenta o ciclo da miséria e da fome. Nesse espaço, a narrativa tece as histórias dos sujeitos anônimos que ali se misturam para encenar o drama da fome. O narrador que as conta, um narrador de $3^{\mathrm{a}}$ pessoa, onisciente, em alguns momentos deixa de narrar e passa a ouvinte, emprestando a palavra às personagens para que contem sua própria história, deixando ver as várias vozes que emergem no texto.

As histórias contadas - e a própria história do mangue - são trazidas para o plano da narração pelos olhos do menino João Paulo, protagonista do romance, que as contrasta com a realidade que ele imagina e deseja. Num relato que mistura brincadeira e fantasia, o menino monta as histórias do mangue. A crueza da realidade diária, já incorporada por ele, é amenizada pelo sonho que projeta outra realidade; um futuro diferente que surge em histórias fabulosas nas quais o menino vence "batalhas terríveis" e se transforma em herói. Ressalte-se, nesse aspecto, o lúdico, o jogo, lembrando a criação - tal como em Morte e vida Severina - intertexto direto com Homens e caranguejos - que, por sua vez, remete ao próprio romance, 
também ele visto como criação e não como reprodução da realidade. Ao mundo hostil de miséria e fome a narrativa contrapõe a atividade imaginativa do menino que desvela os sonhos e desejos não apenas seus, mas de todas as personagens cujas histórias são, por ele e pelo narrador, contadas/rememoradas. Tem-se, assim, que a objetividade factual e a linearidade discursiva são desestabilizadas pelo cruzamento de outros tempos e espaços em que se apresentam segmentos sociais distintos. $\mathrm{O}$ que a princípio seria lugar de podridão e morte, ganha vida no desvelamento dos traumas, dos sonhos e desejos (de fartura, de justiça, de liberdade) que rondam as histórias das personagens. O mangue é constituído, assim, como um espaço que acolhe/engole indivíduos que não se encaixam no modelo estabelecido pela ordem vigente; indivíduos que, mesmo animalizados por sua condição de vida precária, são acolhidos em sua diferença. A diversidade de histórias coincide, pois, com a diversidade de que o próprio mangue se compõe.

$\mathrm{Na}$ ênfase dada ao drama da fome, a narrativa atribui cor, cheiro, textura a ela. Isso se dá pela via do sensorial, ativado, por exemplo, no cheiro podre associado à lama, ou no "barulho das tripas vazias" ou, ainda, na cor negra da miséria que remete à cor da fome, por sua vez lembrando a morte. Do mesmo modo, a construção da metáfora evidencia o processo de dessubjetivação das personagens em que, na relação simbiótica com o ambiente, tal como ocorre com o caranguejo, o homem assume feição de animal. Como em uma cadeia biológica, homem e caranguejo se apropriam da água e da lama do mangue, assim como se apropriam um do outro, dando origem à figura híbrida revelada na metáfora: homem-caranguejo. Interessante é que tal construção se dá a partir da imagem do menino João Paulo que se incorpora ao ciclo do caranguejo ao ser engolido pela lama do mangue. O romance sugere, então, que o homem-caranguejo já nasceria predestinado à fome e à miséria porque fruto da combinação de vários fatores, aí envolvidas relações socioeconômicas injustas. Daí, talvez, a ambiguidade com que o texto se constrói. Num primeiro momento, a esperança é posta na imagem da criança que representaria a libertação de um estado de opressão; a mudança, o desejo, o devir. Entretanto, ainda que o drama da fome, filtrado pelos olhos do menino, seja amenizado pela fantasia e o sonho, esses dois elementos são quebrados pelo olhar do adulto (o do narrador e o do autor) que parece derrubar as expectativas de mudança e liberdade ao mostrar, com a morte da criança, que o ciclo da fome não seria interrompido. 
O jogo dos realismos que configuram os romances é, também, um jogo intertextual na medida em que essas formações discursivas aproximam-se e se distanciam, fazendo parte de um movimento em que muitas vezes um romance retoma o outro, ou uma cena enunciativa lembra outra, porém de modos diferentes. Os próprios contextos e fatos históricos são retomados. Homens e caranguejos, escrito na década de 1960, encena o contexto da seca na década de 1930, o mesmo de Vidas secas, e também fala da seca de 1877, encenada em A Fome. Mas há de se ter em conta que os lugares de enunciação ocupados pelos escritores marcam, também, as diferenças nos modos como concebem a realidade e em como organizam o texto para tratar essa mesma realidade.

No romance de Rodolfo Teófilo, a relação entre vida e morte é tratada de modo opositivo, dando-se ênfase à morte, associada à ideia de podridão do corpo depauperado pela fome, ideia que se estende à paisagem degradada pela seca e à corrosão das instituições sociais. Há um movimento que aponta para um processo de dessubjetivação do homem, na medida em que é objetivado e reificado pela carga naturalista. $\mathrm{O}$ discurso médico-científico predomina na construção das cenas, do narrador e das personagens para apontar o errado, o doente, o que está em desacordo. Dentro de uma formação discursiva realista, o romance de Rodolfo Teófilo adota e repete a base naturalista que vê na ciência a promessa de solução dos problemas sociais, tomados no nível das consequências de determinismos e forças naturais. No plano da construção textual, isso resulta em um empobrecimento das personagens, engessadas em uma visão reducionista das relações sociais quando, na grande maioria das circunstâncias encenadas, não são postas em situação de diálogo, de interlocução, impossibilitando sua construção subjetiva. Por isso mesmo são personagens sem voz, sem nome, subjugadas a uma ordem, silenciadas por um poder imposto.

Guiado pelas ideias cientificistas vigentes na época e incorporadas pela estética naturalista, o texto de Rodolfo Teófilo constrói-se mais colado no factual e no documental, afeito à observação criteriosa, ao estudo de caso, ao escrutínio do corpo e das estruturas sociais, tudo visando a conferir um estatuto de legitimidade ao narrado, dissimulando o ficcional, o que, muitas vezes compromete a qualidade estética do texto. A concepção de realidade que atravessa o romance é aquela que a vê como algo dado previamente. Daí o tratamento da fome no nível do instintivo, como consequência de um determinismo natural. No discurso progressista veiculado pelo romance, alinhado a um projeto de nação ao qual se filia, aparece a necessidade 
de reforma que tem, nos processos de modernização e higienização, os alicerces para a construção do cidadão e da nação pretendidos - ordenamento e limpeza do corpo físico e social. Não é por acaso que o romance elege modelos, de cidadãos e instituições, ficando de fora todos os que aí não se enquadram - negros, prostitutas, desregrados de qualquer natureza, escravos, pobres, retirantes - porque associados à doença, à degradação do corpo físico e moral, à patologia, aos determinismos que os coloca mais próximos do fisiológico que do subjetivo.

A escrita marca o lugar de saber do intelectual reformista, do farmacêutico, cientista e sanitarista que se vale do discurso literário para construir seu discurso sobre a fome. O próprio escritor, do lugar de onde fala, ocupa posição ambígua, incorporada nos discursos de Manuel de Freitas e do narrador. Ao mesmo tempo em que se coloca como uma espécie de porta-voz dos pobres e oprimidos, denunciando abusos, corrupção e injustiças, percebe-se seu alinhamento ao modelo aplainador de um projeto de construção da nacionalidade que escamotearia as diferenças e apagaria identidades e vozes. Tal atitude coincide com o caráter também ambíguo da própria formação discursiva (o naturalismo) que o romance toma por base. Não se pode deixar de mencionar, no entanto, aqueles elementos que, à revelia da intenção de máxima objetividade, contrariam ou pelo menos colocam em causa a imediaticidade naturalista com a qual o romance é construído. Vale mencionar o hibridismo que o perpassa, misturando discursos contrários ao discurso naturalista, como o romântico e o mítico-religioso. Mesmo como esboços, outros elementos apontam para a construção subjetiva, o que também contraria a proposta naturalista: o abraço cúmplice das escravas antes de serem violadas no exame médico, a convulsão da escrava que explode a subjetividade sufocada, as pequenas histórias que deixam ver costumes e tradições do homem sertanejo. De qualquer modo, são apenas esboços de subjetivação, já que a grande maioria das personagens, essas mesmas que o romance diz representar, não têm direito à voz; agem e falam sempre guiadas pela voz do narrador. Isso aponta, já de início, para a impossibilidade de sua construção como sujeitos.

Vidas secas parece retomar algumas cenas enunciativas da formação discursiva naturalista de que se valeu Rodolfo Teófilo. Há muitos elementos em comum: o jogo entre vida e morte, homem e animal, sujeito e objeto. Mas tal relação não é opositiva e sim oscilante. Ora prevalece um elemento ora outro na construção da paisagem e das próprias personagens, numa complexa relação em torno da grande questão que tangencia a constituição subjetiva. De modo contrário ao que ocorre em A fome, há 
um movimento em Vidas secas que tende a realçar a vida que leva as personagens, coexistindo com a morte no mesmo espaço, em direção a um futuro que a desafia.

A concepção de realidade no livro de Graciliano Ramos não aparece como algo dado previamente ou pautado na determinação de leis naturais e biológicas, antes, é regida pelas relações econômicas e de poder. Há determinismos que envolvem a vida das personagens, mas para desmanchar, de modo irônico, essa outra concepção de realidade na qual se pautou a literatura naturalista. $\mathrm{O}$ romance se apropria do discurso realista/naturalista, mas construindo com ele outras cenas que vão, por exemplo, na contramão da ciência quando mostra um saber que existe antes dela; ou do determinismo da raça, ao construir Fabiano como um homem branco. Mesmo que se valha do fato histórico para a construção do enredo, a ênfase não recai sobre ele. Por isso mesmo, os sentidos também não são pretensamente dados, mas construídos na atenção à participação do leitor, já que é no processo da leitura que as relações encenadas pelo romance vão tecidas. A tensão entre homem e sociedade e a própria intenção social do romance de Graciliano Ramos ocorrem no nível da organização textual por meio das escolhas, das seleções, do modo de combinar palavras. No lugar de educar ou moralizar, o romance dá visibilidade às personagens no jogo de aproximação e distanciamento do narrador que, apesar de ocupar o lugar de um saber erudito, letrado, abre espaço para a inserção de outro(s) saber(es). Com isso rasura-se o projeto homogeneizante que quer apagar as diferenças; diferenças que entrariam, na perspectiva do romance, na construção de uma identidade nacional diferente da regida pelo discurso hegemônico.

Vidas secas encena o homem animalizado e objetivado - o que se dá no nível da construção textual - mas, ao mesmo tempo, despe-lhe as máscaras impostas socialmente para realçar sua condição humana, principalmente quando mostra o sonho e o desejo que o move. No lugar de separar espaços, Graciliano Ramos cria, em Vidas secas, um espaço comum, o da escrita, onde, sem estabelecer a dicotomia entre ricos e pobres, opressores e oprimidos, embaralha as vozes, discursos, pontos de vista, lugares de enunciação. Exemplo disso é o modo como o narrador é construído: sem abrir mão de seu lugar de enunciação incorpora em seu discurso, constituído sob um código culto, a perspectiva do homem inferiorizado e oprimido no tecido social, dando-o a ver. Enquanto Rodolfo Teófilo se vale de um saber legitimado para pedagogizar, moralizar e proclamar a necessidade de mudança, Graciliano Ramos questiona a validade desse saber diante de relações que se pautam pela opressão e pelo silenciamento do outro. 
No âmbito da formação discursiva realista/naturalista, Vidas secas representa uma ruptura, uma descontinuidade em relação ao ponto de vista do discurso hegemônico que o romance critica. Na história privilegiada pelo mundo civilizado e capitalista, o romance insere uma história anônima, fora da ordem, deixando ver seu caráter transgressor. Na contramão de tais relações que reificam e animalizam o homem, o romance exibe a construção desse homem na e pela linguagem (mesmo que não manifesta pela palavra).

O romance de Josué de Castro, assim como A fome, marca um lugar de enunciação também ocupado por um cientista e, mais que isso, do cientista dedicado ao estudo da fome. É desse lugar que o escritor quer desnaturalizar o fenômeno. Nesse quadro, o romance se faz espaço onde o escritor também se constitui subjetivamente, já que se vale da literatura para contar sua experiência sobre a fome nas histórias vistas e ouvidas. Assim como em Vidas secas, a fome em Homens e caranguejos não seria determinada por questões de ordem natural, mas decorrente das próprias ações e opções dos homens, sobretudo ligadas a jogos de poder envolvendo questões de ordem econômica e política. Na dicção social do romance, notam-se a crítica e a denúncia a formas de exclusão e opressão, tanto no sertão como na metrópole, igualando, na miséria e na fome, as vítimas da seca e os que ficam fora da ordem estabelecida pela cidade organizada. É então que surge um terceiro espaço que acolhe (ou engole) esses indivíduos oprimidos.

Interessante é que à criação do espaço do mangue corresponde a desse ser híbrido que o habita, o homem-caranguejo, ambos constituídos como restos que a sociedade rejeita. Mesmo que Josué de Castro tenha se valido do discurso técnicocientífico, o que aponta para certa preocupação com o referente, o embaralhamento dos tempos, proporcionado pelo recurso à memória, de onde resgata histórias contadas e ouvidas, mistura o vivido com o imaginado e borra a nitidez das fronteiras, apontando para o caráter de ficcionalidade da escrita.

$\mathrm{O}$ romance de Josué de Castro também enfatiza o aspecto animalizado do homem, que, aliás, sofre um processo de regressão em sua condição humana, na medida em que vai se associando ao animal - o caranguejo. $\mathrm{O}$ tom cientificista que permeia o texto de Josué de Castro, lembrando também a tinta naturalista presente em A fome, associa o aspecto podre do corpo físico (com seus excrementos) e a podridão do corpo social e suas instituições à lama podre do mangue, tudo para reforçar o ciclo da fome. O mangue, tido pela cidade organizada como espaço de exclusão, é (re)construído como uma espécie de sociedade à parte, também 
poderosa e dominadora não em razão de aspectos econômicos e socioculturais, mas por prender em sua lama espessa aqueles que ali entram e se atolam no ciclo da pobreza e da miséria. O homem é associado ao bicho, transmuta-se nele, em um nítido processo de dessubjetivação.

Mas são outras as formas encontradas pelo romance para ir de encontro a esse movimento reificador. Nas brincadeiras e fantasias do menino João Paulo, o apelo à imaginação quebra a imediaticidade e a crueza da realidade da qual ele toma conhecimento. Embaralhando tempos e espaços, as memórias revisitadas e as histórias contadas desestabilizam o tempo linear e ordenado da cidade capitalista com suas fábricas a exigir disciplina e produtividade. No processo de contação das histórias, a linguagem/fala aparece como possibilidade de ressignificação de questões silenciadas a partir das experiências partilhadas no processo de interlocução. No apelo ao sensorial, intimamente ligado à memória, sobressaem os desejos das personagens, ainda que os levem a se mover dentro do próprio espaço do mangue. No entanto, apesar de mostrar os sonhos das personagens, a perspectiva do romance adota a morte, e não a vida, como possibilidade de saída do ciclo da fome, o que se confirma com a morte do menino engolido pela lama. $\mathrm{Na}$ caminhada do menino pelo mangue, lembrando a caminhada de Fabiano e a família, os sonhos e os desejos o movem, mas são interrompidos no final do livro com sua morte que o leva para dentro da lama e o torna, então, alimento para o caranguejo.

No jogo entre vida e morte que não se dissocia da questão do desejo e, por isso mesmo, da subjetivação, é interessante pensar que em A fome, Rodolfo Teófilo encontra uma saída épica no final do livro, em que os eleitos e adaptáveis salvam-se e vencem a morte. Em Vidas secas, Fabiano e a família seguem adiante, movemse em direção a algo que eles mesmos não sabem o que é, mas que representa, exatamente, a movência do sujeito desejante. Josué de Castro, ainda que mostre o desejo, o sonho e a imaginação que habita o universo do menino-personagem, enfatiza o movimento circular para o qual não vê saída, já que em sua caminhada o menino retorna para a lama onde sempre esteve. O que se pode, pois, esboçar em termos de uma conclusão é que o romance de Rodolfo Teófilo está mais no nível da necessidade; Vidas secas, apesar de falar também de necessidades, encaminhase mais para a ordem do desejo e, portanto, da linguagem a constituir sujeitos, enquanto que Homens e caranguejos, transitando entre necessidade e desejo, enfatiza mais o primeiro elemento. 
No que tange à questão da linguagem constituindo subjetividades, é útil pensar no próprio papel do intelectual como mediador pela palavra/ linguagem, configurado por cada escritor. Rodolfo Teófilo vale-se da palavra para falar a palavra do outro, falar no lugar dele, tomado em sua impossibilidade de fala. São muito poucas as vozes que aparecem em seu texto, diminuindo a possibilidade de diálogo e, por isso mesmo, de contradição e conflito. Graciliano Ramos questiona sua capacidade de falar pelo outro, reconhecendo-se incapaz de representar ou ser o porta-voz dos oprimidos. Tal atitude abriria espaço para que esses indivíduos não representados pudessem se constituir subjetivamente, na medida em que assumiriam seu lugar de enunciação no espaço do texto. Josué de Castro, de certa forma, também se exime de falar no lugar do outro, talvez por sua pouca mobilidade em razão dos direitos políticos cassados pela ditadura. Desse modo, opta por mostrar a realidade social a partir das imagens criadas pela ativação da memória e das histórias contadas. Mesmo assim, as vozes que se ouvem no texto são agenciadas por um narrador que deixa ver o tom pedagógico do romance a conduzir e ensinar por meio daquilo que mostra.

Os três autores, em seus romances, cada um a seu modo, falaram sobre um assunto incômodo, a fome, que agride e violenta o sujeito em sua condição humana. Só por isso já teriam se marcado como enunciações que, de alguma forma, afetaram o leitor, mesmo que o livro de Graciliano Ramos, pelas escolhas estéticas, o trabalho com a palavra, a organização do texto se sobressaia em relação aos outros dois.

Em se falando de morte, de vida, de construção subjetiva pela linguagem, há de se pensar que a literatura é, ela mesma, uma forma de vida porque, como disse Blanchot (2005), escreve-se contra a morte ou pelo menos para se fugir dela. Assim também ocorre com a leitura, pois tudo o que a literatura fala/encena só pode produzir sentido quando confrontado pela subjetividade do leitor. Se, como fala Antonio Candido, a literatura é uma necessidade e um direito, literatura e leitura são formas de preservação da vida, mesmo que o leitor se depare com textos que privilegiam a morte. 


\title{
Realism and (de)construction of subjectivity: faces of hunger in three moments of the Brazilian litera- ture
}

\begin{abstract}
This text discusses how and through which ways subjective construction occurs in three novels of Brazilian literature: A fome, by Rodolfo Teófilo; Vidas secas, by Graciliano Ramos and Homens e caranguejos, by Josué de Castro. Those novels, usually taken as realist ones, written in different times and contexts, have as a common characteristic the dealing with the theme of hunger. Considering those novels as constructions in which the concepts of real and reality are understood in different ways, the option was to approximate the concept of realism to the concept of discursive formation (Foucault, 1995), this one taken as a knowhow made up of discursive practices about something, involving subjects that hold different positions according to the time and space from which they enunciate. The concept of discursive formation is also in line with the concept of subjective construction in so far as, the subjects, as language beings, constitute themselves and the things at the moment they talk, building meanings in and through the relationships that enfold them. From this point of view, the proposition is to understand reality and realism itself in their moving boundaries, the places where languages, subjects, times and spaces are at stake.
\end{abstract}

Keywords: Hunger. Realism. Discursive formation. Novel. Subjectiveness.

\section{Referências}

BAKHTIN, Mikhail Volochínov. Questões de literatura e de estética: a teoria do romance. Tradução de Aurora Fornoni Bernardini et al. 6. ed. São Paulo: Hucitec Editora, 2010.

BENVENISTE, Émile. A linguagem e a experiência humana. In: BENVENISTE, Émile. Problemas de linguística geral II. Tradução de Eduardo Guimarães et al. Campinas: Pontes, 1989a. p. 68-80.

BENVENISTE, Émile. Da subjetividade na linguagem. In: BENVENISTE, Émile. Problemas de linguística geral I. Tradução de Maria da Glória Novak e Maria Luisa Neri. 5. ed. Campinas, SP: Pontes Editores, 2005. p. 284-293.

BENVENISTE, Émile. O aparelho formal da enunciação. In: BENVENISTE, Émile. Problemas de linguística geral II. Tradução de Eduardo Guimarães et al. Campinas: Pontes, 1989b. p. 81-90. 
BLANCHOT, Maurice. O encontro do imaginário. In: BLANCHOT, Maurice. O livro por vir. Tradução de Leyla Perrone-Moisés. São Paulo: Martins Fontes, 2005. p. 3-13.

CANDIDO, Antonio. A revolução de 1930 e a cultura. Novos Estudos CEBRAP, São Paulo, v. 2, n. 4, p. 27-36, abr. 1984. Disponível em: <http://novosestudos.uol. com.br/v1/files/uploads/contents/42/20080623_revolucao_de_1930_e_a_cultura. pdf. Acesso em: 7 jul. 2016.

CASTRO, Josué de. Homens e caranguejos. 4. ed. Rio de Janeiro: Civilização Brasileira, 2010.

FOUCAULT, Michel. Arqueologia do saber. Tradução de Luiz Felipe Baeta Neves. 4. ed. Rio de Janeiro: Forense Universitária, 1995.

MELO NETO, João Cabral de. Morte e vida severina. Rio de Janeiro: Record, 1996.

RAMOS, Graciliano. Vidas secas. 75. ed. Rio, São Paulo: Record, 1998.

RANCIÈRE, Jacques. A partilha do sensível: estética e política. 2. ed. Tradução de Mônica Costa Netto. São Paulo: EXO experimental, 2009.

TEÓFILO, Rodolfo. A fome: cenas da seca do Ceará. São Paulo: Tordesilhas, 2011.

Recebido em 27/09/2016

Aceito em 06/11/2016 